\title{
ADMINISTRATIVE ACCOUNTING CONSULTING: A NEW WAY OF RUNNING A COMPANY THROUGH TECHNOLOGY
}

\section{ORIGINAL ARTICLE}

SUMAR, Ramiro Rodrigues ${ }^{1}$

SUMAR, Ramiro Rodrigues. Administrative accounting consulting: a new way of running a company through technology. Revista Científica Multidisciplinar Núcleo do Conhecimento. Year 06, Ed. 07, Vol. 12, pp. 91-104. July 2021. ISSN: 2448-0959, Access Link: https://www.nucleodoconhecimento.com.br/businessadministration/through-technology,

DOI: 10.32749/nucleodoconhecimento.com.br/business-administration/through-technology

\section{ABSTRACT}

Objective: To describe the impact from the obstacles and potentialities that technology has brought to accounting consulting. Question: How can administrative accounting consulting help a company using technologies? Methods: The study is a bibliographic review. A search was conducted with the descriptors: technology; innovation; accounting; accounting on Spell's data platform (Scientific Periodicals Electronic Library) in June 2021. The search resulted in 10 articles. Results: the results brought as obstacles: The increasing technological advance, adapt to the use of these new technologies, Centrality of the role of the accountant in traditional models, Lack of software knowledge,Lack of specialized workforce, malfunction of the connection, Skilled labor. And as potentialities: Use of different digital technologies, Agility and time gain, Convenience, inseparable relationship between technology and consultative accounting promoting agile and quality support to its various users, Customer satisfaction, Speed and flexibility and Cost reduction.

\footnotetext{
${ }^{1}$ Master's degree in Controllership, Specialist in Technology Management, Strategic Administration, Information Security and Graduated in Accounting Sciences.
}

RC: 93884

Disponível em: https://www.nucleodoconhecimento.com.br/business- 
Conclusions: It is understood that Information Technologies positively influence the exercise of consultative accounting, although in addition to the advantages has its disadvantages. It is worth mentioning that the technologies enable the control of accounting information for the entry and exit of materials and inputs, as well as their origin and final destination, avoiding unnecessary losses, including deviations, agility, flexibility and security.

Keywords: Consulting, Innovation, Technological means, Information security.

\section{INTRODUCTION}

The link between accounting and technologies has perpetuated for decades, since, in addition to being science, accounting is one of the information systems used in older business management, which makes the accounting of the past and the accounting of the present different are the ways in which they lead to business management (FERREIRA et al., 2017).

Technology has been advancing over the years, innovating so that the need for the human being is met. Therefore, being an unlimited tool, the evolution of technologies combined with accounting brings relevant contributions to the growth of organizations (SILVA et al., 2020).

The continuous use of computer networks and the combination of various accounting instruments favor storage, registration, processing and facilitatethe realization of the crossing of information increasingly faster, which enables safer decision-making within the organization (MARION; RIBEIRO, 2017; DE ANDRADE SIMÕES et al., 2021).

Currently, the search for information has been useful and at the same time relevant to the growth of the organization. The transfer of information to knowledge, as well as the timely application of knowledge in practice and the distribution of these acts for

RC: 93884

Disponível em: https://www.nucleodoconhecimento.com.br/business- 
the development of a company, are potentialities of technology in favor of consultative accounting for the entrepreneur.

However, many accountants do not use this tool as a way to gain space, time and retain their customers, making it clear that in some situations, the technologies for the counters are not used. In this placement, identifying the problematization of the study in question, there is the question that guided the theme of this study: How can administrative accounting consulting help a company using technologies?

The current labor market often motivates people to reformulate themselves in their professional activities, because the basic university education system and new knowledge still become few in view of the practice that the student will perform after graduating.

According to Villa et al (2012, p.107), "traditional accountants have a view that entrepreneurs do not seek the knowledge necessary to manage their business, that is, they do not take improvement courses or training in administration". To paraphrase this quote from the author, indicates that the entrepreneur only has the interest to meet the demands of taxes, thus forgetting the competitive market, which causes the company to lose space and not develop in its quality.

In this placement, the importance of the advisory counter is observed. This work is added to the researcher's justification of understanding why many accountants do not use consultative accounting to work with their clients, since this help tool especially in the pandemic times of the new coronavirus exerts influence so that the company is not at risk of having commitment in its income in the competitive market.

Therefore, the subject becomes relevant, because with the advent of technologies, the accounting of companies took a different direction from accounting decades ago and with this, the accountant now has the responsibility and commitment to make his profession identified by society and entrepreneurs as a profession that is advancing

RC: 93884

Disponível em: https://www.nucleodoconhecimento.com.br/business- 
to adapt to technological means in order to ensure more security and reliability to organizations.

Therefore, this work has as its general objective: To describe the impact from the obstacles and potentialities that technology has brought to accounting consulting.

\section{METHODOLOGICAL PROCESS}

This study is a systematic bibliographic review of a qualitative nature. According to Sampaio and Mancini (2007) this type of study is carried out through the search of articles relevant to the theme researched, based on the synthesis of relevant subjects combined with systematized methods of investigation, critical analysis, summary of the information chosen and important problems that require further studies.

To carry out the research, the following steps recommended by Sampaio and Mancini (2007): Formulation of the guide question of the study were followed; Location of studies; Critical evaluation of studies; Data collection; Data analysis; Ethical aspects.

From the construction of a guide question, some assumptions arise that guide and/or delimited this study, thus enabling to highlight the applicability of technologies in the universe of consulting the numbers and values to which the accountant is inserted. The question that guided the topic was: How can administrative accounting consulting help a company using technologies?

The material was selected in the databases: Spell (Scientific Periodicals Electronic Library). The study sample consisted of articles (original research; review articles; monographs, theses and dissertations). Articles in Portuguese and English were used as inclusion criteria, from 2016 to 2020 that are available in full and free of charge. All articles that were framed in these criteria, which in their area of

RC: 93884

Disponível em: https://www.nucleodoconhecimento.com.br/business- 
knowledge covered accounting and had as title or abstract subjects relevant to the use of technologies were framed for the research. Other articles that were not included or duplicated were excluded. The keywords used to search for these articles in Spell were: technology; innovation; accounting; consultative accounting.

The critical evaluation of the productions that were selected and included in the study gave rise to interpretations and synthesis of the results, identifying the scientific information present in each study and the relevant factors for the study in question suggesting guidelines for future research. To validate the study, the researcher makes clear which gaps were found in the study and what future paths other researchers can adopt in their scientific research. The main information was arranged in tables, making clear the information pertinent to the results of the articles, comfacing the subjects with the literature pertinent to the subject.

Data were collected during June 2021. The collection was performed including the inclusion and exclusion criteria of the articles. Also, emphasizing that the research also seeks, based on the analysis performed, to report on consultative accounting and the use of technologies. Two searches were made interspersing the keywords.

The data found in the published literature occurred according to Ercole's proposal; Melo and Alcoforado (2014), in which the reviewer should seek to evaluate the results impartially, seeking explanations for the different or conflicting results in the different studies.

\section{ANALYSIS OF RESULTS AND DISCUSSIONS}

The searches resulted in a total of 343 results with the keywords. All titles and abstracts were read and articles that could respond to the objectives of the study in question were removed, resulting in 10 studies.

RC: 93884

Disponível em: https://www.nucleodoconhecimento.com.br/business- 
Thus, we present a picture with the title of the article, authors, year of publication (Reference), objective of the study and results found.

Table 1 - Selected articles

\begin{tabular}{|c|c|c|}
\hline & Goals & Findings \\
\hline $\begin{array}{l}\text { No caminho da } \\
\text { inovação: análise das } \\
\text { capacidades de } \\
\text { inovação de empresas } \\
\text { contábeis diante das } \\
\text { tecnologias digitais }\end{array}$ & $\begin{array}{l}\text { Examine the innovation } \\
\text { capacity of accounting } \\
\text { offices in the Brazilian } \\
\text { market, in the use of } \\
\text { digital technologies, } \\
\text { based on the capabilities } \\
\text { of technology } \\
\text { development, operation, } \\
\text { management and } \\
\text { transaction. }\end{array}$ & $\begin{array}{l}\text { Accounting begins on the } \\
\text { traditional path of digital } \\
\text { innovation, demonstrating the } \\
\text { quality and value that } \\
\text { technological solutions can } \\
\text { generate when exploited in } \\
\text { business and especially in } \\
\text { processes. This increase in } \\
\text { technology causes changes in } \\
\text { accounting business models. }\end{array}$ \\
\hline $\begin{array}{l}\text { Indústria } 4.0 \text { e } \\
\text { avanços tecnológicos } \\
\text { da área contábil: perfil, } \\
\text { percepções } \\
\text { expectativas dos } \\
\text { profissionais } \\
\text { Xavier; Carraro and } \\
\text { Rodrigues (2020). }\end{array}$ & $\begin{array}{l}\text { Analyze the profile of the } \\
\text { accounting professional in } \\
\text { the face of technological } \\
\text { advances, aiming to } \\
\text { explore how he behaves } \\
\text { in relation to new trends. }\end{array}$ & $\begin{array}{l}\text { Most professionals are } \\
\text { interested in adapting to new } \\
\text { technologies to meet the } \\
\text { requirements of the function. } \\
\text { However, there were some } \\
\text { resistances to the changes, } \\
\text { especially among professionals } \\
\text { under } 35 \text { years of age and in } \\
\text { the corporate area. }\end{array}$ \\
\hline $\begin{array}{l}\text { Características dos } \\
\text { Diferentes Modelos de } \\
\text { Negócios Contábeis } \\
\text { em Relacão às Áreas }\end{array}$ & $\begin{array}{l}\text { Identify the value } \\
\text { delivered to the client of } \\
\text { accounting services, } \\
\text { through the structural }\end{array}$ & $\begin{array}{l}\text { The accounting area focused } \\
\text { on Information Systems has its } \\
\text { deliveries based on consulting } \\
\text { in data processing, information }\end{array}$ \\
\hline
\end{tabular}

RC: 93884

Disponível em: https://www.nucleodoconhecimento.com.br/business- 


\begin{tabular}{|c|c|c|}
\hline $\begin{array}{l}\text { Schiavi and Behr } \\
\text { (2020). }\end{array}$ & $\begin{array}{l}\text { organization of } \\
\text { characteristics business } \\
\text { traditional areas of } \\
\text { models, in relation to their } \\
\text { respective areas } \\
\text { activity in accounting. }\end{array}$ & $\begin{array}{l}\text { technology and operating } \\
\text { systems. }\end{array}$ \\
\hline $\begin{array}{l}\text { As Contribuições da } \\
\text { Contabilidade } \\
\text { Consultiva: Um Estudo } \\
\text { de Caso/The } \\
\text { Contributions of } \\
\text { Advisory Accounting: } \\
\text { A Case Study } \\
\text { Angelim and Barreto } \\
(2020) \text {. }\end{array}$ & $\begin{array}{l}\text { Check the contributions } \\
\text { promoted by the } \\
\text { advancement } \\
\text { technology in accounting } \\
\text { as well as advisory } \\
\text { accounting. }\end{array}$ & $\begin{array}{l}\text { It was found that the perceive } \\
\text { the importance of consultative } \\
\text { accounting in the current } \\
\text { scenario as well as the } \\
\text { essential role of technology in } \\
\text { the accounting profession. The } \\
\text { challenges addressed by the } \\
\text { surveyed include adapting to } \\
\text { the use of new technological } \\
\text { tools, the need to outline } \\
\text { strategies to better serve the } \\
\text { client and the need to know the } \\
\text { management and business of } \\
\text { each client. }\end{array}$ \\
\hline $\begin{array}{l}\text { Impact of information } \\
\text { technology on } \\
\text { accounting line of } \\
\text { works } \\
\text { Asuquo; Dan and } \\
\text { Effiong (2020). }\end{array}$ & $\begin{array}{l}\text { Determine the impact of } \\
\text { information technology on } \\
\text { the accounting line of } \\
\text { works in the global } \\
\text { system. }\end{array}$ & $\begin{array}{l}\text { Research results showed that } \\
\text { information technology has a } \\
\text { substantial influence on the } \\
\text { accounting line of work. }\end{array}$ \\
\hline $\begin{array}{l}\text { The impact } \\
\text { information }\end{array}$ & $\begin{array}{l}\text { Examine the advantages } \\
\text { of information technology }\end{array}$ & $\begin{array}{l}\text { Accounting, such as the } \\
\text { language of business and }\end{array}$ \\
\hline
\end{tabular}

RC: 93884

Disponível em: https://www.nucleodoconhecimento.com.br/business- 


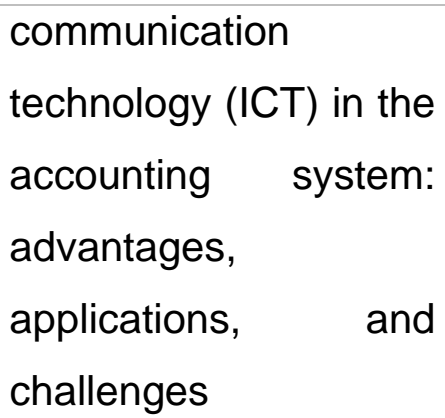

The Impact of Identify whether the Research has shown that Quality of Accounting to new technologies to serve users of financial information. In the information age, market requirements for accounting graduates are changing progressively. speed and flexibility are the most technological effect on accounting applications with improved and reliable characteristics. Information

Technology on The
Information (SFAC NO 8, 2010)

Al Natour (2020). technology has had an effect (positive negative) on accounting applications and whether information technology in accounting has an effect on the quality of financial reports in Saudi Arabia.

A Consultoria Contábil como Oportunidade de Negócios Profissionais - Um Estudo Documental

Almeida et al (2018).

Consultoria

Organizacional como um Instrumento de Inovação em Arranjos

\section{Conduct a documentary} and bibliometric study on accounting consulting in the period from 2006 to 2016.

\begin{tabular}{lr|lr} 
Analyze & how & The consultancies & provided \\
organizational consulting & innovations for & most \\
practices can trigger & businesses, being $89 \%$ in \\
innovation in Local & processes, $77 \%$ in business \\
Productive Arrangements & management, 74\% in products
\end{tabular}

The accounting consultancy presents a qualitative financial return factor for companies, consequently increasing the competitive advantage for them. 


\begin{tabular}{|c|c|c|}
\hline Produtivos Locais & (APLs). & and $40 \%$ in marketing. \\
\hline $\begin{array}{l}\text { Silva; Ribeiro e Silva } \\
\text { (2018). }\end{array}$ & & \\
\hline $\begin{array}{l}\text { Planejamento } \\
\text { Estratégico: } \\
\text { Diagnóstico de } \\
\text { Proposta } \\
\text { Intervenção por Meio } \\
\text { de Consultoria } \\
\text { Gafuri; Rojo and Miura } \\
\text { (2017). }\end{array}$ & $\begin{array}{l}\text { Diagnose and present } \\
\text { intervention proposals } \\
\text { through consulting that } \\
\text { contributes to the } \\
\text { formatting of a strategic } \\
\text { planning for a company } \\
\text { active in the business of } \\
\text { boutique women's } \\
\text { footwear and } \\
\text { accessories. }\end{array}$ & $\begin{array}{l}\text { Through an external consulting } \\
\text { approach, an external view of } \\
\text { the organization, it is } \\
\text { indispensable to adapt the } \\
\text { techniques and tools to the type } \\
\text { of business that is analyzed, as } \\
\text { well as the activity performed, } \\
\text { size of the company and the } \\
\text { volume of negotiations. }\end{array}$ \\
\hline
\end{tabular}

Source: Own Authorship

The selected articles identified obstacles to the use of technologies by the counter. Table 2 provides a synthesis of these difficulties from the reference of the selected article.

Table 2 - Obstacles encountered

Article Title, Reference

No caminho da inovação: análise das capacidades de inovação de empresas contábeis diante das tecnologias digitais Indústria 4.0 e avanços tecnológicos da área contábil: perfil, percepções e

\section{Obstacles encountered}

The growing technological advance

Adapt to the use of these new technologies

RC: 93884

Disponível em: https://www.nucleodoconhecimento.com.br/business- 
expectativas dos profissionais

Características dos Diferentes Centrality of the role of the accountant Modelos de Negócios Contábeis em in traditional accounting business Relação às Áreas da Contabilidade models, and technological resources are still supporting in this scenario.

As Contribuições da Contabilidade Adapting to the use of new Consultiva: Um Estudo de Caso/The technological tools

Contributions of Advisory Accounting:

\section{A Case Study}

Impact of information technology on

Retain the detectable tastes of your accounting line of works past rooted in character and integrity

The impact of information and Inexperienced project managers; Lack communication technology (ICT) in the accounting system: advantages, applications, and challenges

\section{The Impact of Information} Technology on The Quality of Accounting Information (SFAC NO 8, of software knowledge; Incomplete contracts; Lack of specialized workforce. 2010)

\begin{tabular}{|c|c|c|c|}
\hline & & \multirow{2}{*}{$\begin{array}{l}\text { Longer duration and allocation of larger } \\
\text { resources and execution costs. }\end{array}$} \\
\hline & \multicolumn{2}{|c|}{ Contábil como } & \\
\hline $\begin{array}{l}\text { A Consultorla } \\
\text { Oportunidade } \\
\text { Profissionais }\end{array}$ & _ Um Estudo & Estudo & \\
\hline \multicolumn{4}{|c|}{ Documental } \\
\hline \multicolumn{3}{|c|}{ Consultoria Organizacional como um } & \multirow[t]{2}{*}{ Skilled labor. } \\
\hline \multicolumn{3}{|c|}{ Instrumento de Inovação em } & \\
\hline
\end{tabular}

$\mathrm{RC}: 93884$

Disponível em: https://www.nucleodoconhecimento.com.br/business- 
Arranjos Produtivos Locais

Planejamento Estratégico: Lack of software knowledge.

Diagnóstico e Proposta de

Intervenção por Meio de Consultoria

Source: Own Authorship

It is observed that there are several obstacles evidenced in the articles when it comes to the use of technologies for accounting consulting. These obstacles come mostly from the difficulties of many professionals not adapting to the use of technologies in their routine, or because the professional is not properly qualified or qualified, or for fear of technological changes.

Schiavi et al (2020) points out that technologies should be seen as a support to aim for good results especially in consultancies, however, the accountant should be aware of technological advances that are not slow, which allows the professional to be afraid to use technology as a targeted support for consulting.

Xavier; Carraro and Rodrigues (2020) mention that consultative accounting needs to be directed from technological means, because it favors more security, precision and reliability in the data found, however, for this to happen, it is up to the accountant to be aware of the changes in technological advances and adapt to the entire system, bringing to the customer advanced and first-line technologies.

Schiavi and Behr (2020) and Angelim and Barreto (2020) report that a portion of accounting professionals still have their domain in the traditionality of accounting science, not allowing the total presence of technologies for the best quality in accounting consulting services, which reflects a significant delay in the discovery of decision-making.

RC: 93884

Disponível em: https://www.nucleodoconhecimento.com.br/business- 
It makes it necessary for the professional to be aware of the new technological trends for the improvement of the company, an accountant trained in the use of technologies tends to reduce the time to achieve the balance of the company, as well as manage to pass reliability in the collected data.

According to Asuquo; Dan and Effiong (2020) consultative accounting brings the opportunity to expand in all sectors of accounting, whether in a managerial or financial way, what determines the work of consulting is the reason why consulting will be worked, however, the rooting of traditional accounting, creates a huge obstacle between the accountant and technologies, where this professional still feels safer in the presence of the client in his office.

The lack of knowledge of the technologies and their benefits still permeate the lives of many professionals. Lack of professional training, lack of knowledge about programs, skilled labor among other obstacles allow technologies to fail to enter accounting consulting and thus, favor quickly, safely and effectively, data analysis and, consequently, decision-making (AL-SHAFEAY; AL_DUJAILI; AL-WATTAR, 2020; ALMEIDA et al., 2018; SILVA; RIBEIRO; SILVA, 2018; GAFURI, ROJO; MIURA, 2017).

However, the obstacles not only relate to the difficulties of accountants in the use of technologies, the malfunction of programs, the slowness of the Internet, viruses in the computer can influence the non-suitability of the professional to the medium of technologies to aid in consultative accounting (AL NATOUR, 2020).

The use of Software and Hardware requires an intense dedication of the professional to be able to know how to use the tools and with this present methods that can bring lower costs and greater benefits to the company. Considering these obstacles in their complexities of the technological environment, it identifies the potentialities that technologies can bring to accounting consulting.

RC: 93884

Disponível em: https://www.nucleodoconhecimento.com.br/business- 
Table 3 - Potential for accounting consulting and the use of technologies

\section{Article Title, Reference}

No caminho da inovação: análise das capacidades de inovação de empresas contábeis diante das tecnologias digitais

Indústria 4.0 e avanços tecnológicos da área contábil: perfil, percepções e expectativas dos profissionais

\section{Características dos Diferentes} Modelos de Negócios Contábeis em Relação às Áreas da Contabilidade

As Contribuições da Contabilidade Consultiva: Um Estudo de Caso/The Contributions of Advisory Accounting:

\section{A Case Study}

Impact of information technology on accounting line of works

The impact of information and communication technology (ICT) in the accounting system: advantages, applications, and challenges

The Impact of Information Technology

\section{Potential}

Use of different digital technologies; act fully online to bring more accessibility and agility in the provision of accounting services

Agility and time gain. Convenience.

The use of the use of the user's technological means such as e-mails, telephone, among others to carry out accounting consulting.

Inseparable relationship between technology and consultative accounting promoting agile and quality support to its various users.

Satisfy your internal and external audiences by giving them quality and performance services on a continuous and consistent basis.

Customer satisfaction; Agility; Reliability.

Speed and flexibility

RC: 93884

Disponível em: https://www.nucleodoconhecimento.com.br/business- 
on The Quality of Accounting Information (SFAC NO 8, 2010)

A Consultoria Contábil como Risk-prone to the expected results of Oportunidade de Negócios the work to be carried out

Profissionais - Um Estudo

Documental

Consultoria Organizacional como um Instrumento de Inovação em Arranjos

Produtivos Locais

New methods of work organization; New techniques for Knowledge Management; Significant changes in relationships with other companies

Planejamento

Estratégico: Cost reduction, management control Diagnóstico e Proposta de Intervenção por Meio de Consultoria with unfolding for purchasing schedules.

Source : propre auteur

It is evident that the need to delve into new concepts and knowledge is of paramount importance for accounting professionals, for this, the potential of technologies on accounting consulting is observed. Accounting is considered as a fundamental tool to support the growth of the company, however, the lack of knowledge of technologies by the accountant makes this acquired knowledge identified in the traditionality of the roles.

Schiavi et al. (2020) mention several potentialities that technologies can favor accounting consulting, the citation is: Use of different digital technologies; act fully online to bring more accessibility and agility in the provision of accounting services. These positions by the authors identify the importance of accounting and technologies always moving alongside each other, which favors the accountant's loyalty of their customers.

RC: 93884

Disponível em: https://www.nucleodoconhecimento.com.br/business- 
Xavier; Carraro and Rodrigues (2020) corroborate with the above authors on the potential ities of technologies for accounting consulting and reinforce that in addition to these placements can also be mentioned to agility, time gain and convenience of both the company and the accountant.

For Schiavi and Behr (2020) using technologies to carry out accounting consulting is not only related to issues of computer programs, telephone, social networks, e-mails, among other technologies can help the traditional accountant to carry out his consulting without necessarily having to work with programs.

According to Angelim and Barreto (2020) technologies already have their participation in advisory accounting, however, the presence of facilitating programs for the realization of accounting consulting has led to what is called innovation technology, bringing agility and more reliability in the data presented.

According to Asuquo; Dan and Effiong (2020) and Al-Shafeay; Al Dujaili and AlWattar (2020), consultative accounting aims to provide the most reliable information about the company and the results it obtains, customer satisfaction by bringing quality and performance services is what demonstrates the difference of the presence of the most advanced technology for the accountant.

Al Natour (2020) that technologies are fast and flexible, two essential conditions for the work of the accountant who in his consulting time becomes an enemy for decision making, since the competitive market is increasingly demanding in relation to companies.

According to Almeida et al. (2018) trends to increase a company's profit directly impact the accountant, which intensifies accounting's knowledge of risk-taking. The technologies act in order to ensure less risk to the accountant and better profitability to the company, which allows the customer and the company owner a quality service and in an agile time.

$\mathrm{RC}: 93884$

Disponível em: https://www.nucleodoconhecimento.com.br/business- 
Silva; Ribeiro e Silva (2018) e Gafuri; Rojo and Miura (2017) emphasize that in addition to providing accurate and safe analysis, technologies also provide methods of work organization, knowledge management, better relationship with other companies, control in costs, an improvement in decision making, among other potentialities aiming at greater productivity with lower costs compared to traditional and manual techniques.

It is perceived that technologies combined with consultative accounting have several potentialities which allows accounting to have its decision-making so that the company does not run financial problems or leave the competitive market, acting on top of the problem evidenced.

\section{FINAL CONSIDERATIONS}

The obstacles to the use of technologies in consultative accounting are still something of concern, considering that the accounting professional should have as an aid to technology to improve their service and that the non-acceptance of the use of technologies can cause this professional to be disqualified and discredited from his duties.

The accounting professional must keep in mind sustainable practices to be able to raise more financial and operational benefits for companies, considering that in addition to the high cost of acquisition and maintenance of the entire technological installation process, there are expenses regarding qualification and professional training.

The growing demand for computer programs directly influences the non-acceptance of many professionals, this can be considered in a disadvantageous way for accounting, since there is no single system to perform the necessary activities that accounting needs.

$\mathrm{RC}: 93884$

Disponível em: https://www.nucleodoconhecimento.com.br/business- 
But the potential that technological advances bring to accounting consulting are immense, and these potentialities can generate positive impacts regarding the acceptance of the use of technologies to achieve the goals in accounting. In this context, it has been that technologies facilitate the overall view of the counter, in which the perception of a smaller margin of error and access to all data of interest that can be compiled and /or billed, finds in technology an ally to perform a service of excellence.

It is considered, therefore, that the study achieves its objective listed and refers as a gap to research conducted based on accounting consulting in general, which opens ways for new research to be idealized extending this theme to a more restricted form such as financial or even managerial accounting consulting.

\section{REFERENCES}

ALMEIDA, Leonardo Soares Francisco de et al. A Consultoria Contábil como Oportunidade de Negócios Profissionais-um Estudo Documental. Pensar Contábil, v. 20, n. $72,2018$.

AL NATOUR, Jihad Rebhee Abdel Qader et al. The Impact of Information Technology on The Quality of Accounting Information (SFAC NO 8, 2010). Turkish Journal of Computer and Mathematics Education (TURCOMAT), v. 12, n. 13, p. 885-903, 2020.

AL-SHAFEAY, Karrar Mohammed; AL_DUJAILI, Mohammed Jawad; AL-WATTAR, Yasir Mohammed Ali. The impact of Information and Communication Technology (ICT) In the accounting system: advantages, applications, and challenges. PalArch's Journal of Archaeology of Egypt/Egyptology, v. 17, n. 6, p. 15814-15825, 2020.

ANGELIM, Vitória Ribeiro; BARRETO, Tayssa Vieira. As Contribuições da Contabilidade Consultiva: Um Estudo de Caso/The Contributions of Advisory

RC: 93884

Disponível em: https://www.nucleodoconhecimento.com.br/business- 
Accounting: A Case Study. ID on line Revista de Psicologia, v. 14, n. 52, p. 317331, 2020.

ASUQUO, Akabom I.; DAN, Nicholas O.; EFFIONG, Glory T. Impact of information technology on accounting line of works. International Journal of Recent Technology and Engineering, v. 9, n. 2, p. 1572-1577, 2020.

DE ANDRADE SIMÕES, Maervelym Pâmella et al. Benefícios do uso da tecnologia Blockchain como instrumento para a auditoria contábil. Revista ambiente contábilUniversidade Federal do Rio Grande do Norte-ISSN 2176-9036, v. 13, n. 1, p. 3953, 2021.

ERCOLE, Flávia Falci; MELO, Laís Samara de; ALCOFORADO, Carla Lúcia Goulart Constant. Revisão integrativa versus revisão sistemática. Revista Mineira de Enfermagem, v. 18, n. 1, p. 9-12, 2014.

FERREIRA, Tiago Janes et al. Automação contábil: tecnologia em contabilidade sob a ótica da teoria institucional. XI Congresso ANPCONT. 3 a 6 de junho de 2017. Belo Horizonte, Minas Gerais.

GAFURI, Raquel Adriana Pin; ROJO, Cláudio Antonio; MIURA, Marcio Nakayama. Planejamento estratégico: diagnóstico e proposta de intervenção por meio de consultoria. Revista Capital Científico-Eletrônica (RCCe)-ISSN 2177-4153, v. 15, n. 1, p. 139-155, 2017.

MARION, JOSE CARLOS; RIBEIRO, OSNI MOURA. Introdução à contabilidade gerencial. Saraiva Educação SA, 2017. Disponível em: https://books.google.com.br/books?hl=pt-

$B R \& \mid r=\& i d=k D 1 n D w A A Q B A J \& o i=f n d \& p g=P T 5 \& d q=I n t r o d u \% C 3 \% A 7 \% C 3 \% A 30+\% C$ $3 \% \mathrm{~A} 0+$ contabilidade+gerencial. $+\&$ ots $=J j \mathrm{jSnq} 2 \mathrm{mD} 0 \&$ sig $=\mathrm{vcUiQXgi1UkNhLanfgWU67}$

RC: 93884

Disponível em: https://www.nucleodoconhecimento.com.br/business- 
QVgas\#v=onepage\&q=Introdu\%C3\%A7\%C3\%A30\%20\%C3\%A0\%20contabilidade\% 20gerencial. $\& f=$ false

SAMPAIO, Rosana Ferreira; MANCINI, Marisa Cotta. Estudos de revisão sistemática: um guia para síntese criteriosa da evidência científica. Brazilian Journal of Physical Therapy, v. 11, p. 83-89, 2007.

SCHIAVI, Giovana Sordi; BEHR, Ariel. Características dos diferentes modelos de negócios contábeis em relação às áreas da Contabilidade. REUNIR Revista de Administração Contabilidade e Sustentabilidade, v. 10, n. 3, p. 47-59, 2020.

SCHIAVI, Giovana Sordi et al. No caminho da inovação: análise das capacidades de inovação de empresas contábeis diante das tecnologias digitais. Revista Brasileira de Gestão de Negócios, v. 22, p. 381-405, 2020.

SILVA, Gustavo Oliveira et al. O impacto da tecnologia na profissão contábil sob perspectivas de pessoas com formação e/ou experiência profissional na área. Contribuciones a las Ciencias Sociales, n. 72, p. 3, 2020.

SILVA, Fabiana Ferreira; RIBEIRO, Ana Regina Bezerra; SILVA, Washington Ferreira. Consultoría Organizacional como um Instrumento de Inovação em arranjos produtivos locais. Revista Organizações em Contexto, v. 14, n. 27, p. 29-52, 2018.

VILLA, Patricia et al. O monólogo contábil: uma análise do uso da contabilidade gerencial em micro e pequenas empresas à luz do processo comunicacional segundo Bakhtin". Monografia para obtenção de título de mestrado em contabilidade. UFPR, 2012.

XAVIER, Leonardo Montes; CARRARO, Wendy Beatriz Witt Haddad; RODRIGUES, Ana Tércia Lopes. Indústria 4.0 e avanços tecnológicos da área contábil: perfil, percepções e expectativas dos profissionais. Contexto. Porto Alegre, RS. Vol. 20, n. 45 (maio/ago. 2020), p. 34-50, 2020.

$\mathrm{RC}: 93884$

Disponível em: https://www.nucleodoconhecimento.com.br/businessadministration/through-technology 
Submitted: July, 2021.

Approved: July, 2021.

$\mathrm{RC}: 93884$

Disponível em: https://www.nucleodoconhecimento.com.br/business-

administration/through-technology 